

University of Kentucky

UKnowledge

Fall 2017

\title{
An Empirical Study of University Patent Activity
}

Brian L. Frye

University of Kentucky College of Law, brianlfrye@uky.edu

Christopher J. Ryan

Vanderbilt University

Follow this and additional works at: https://uknowledge.uky.edu/law_facpub

Part of the Intellectual Property Law Commons

Right click to open a feedback form in a new tab to let us know how this document benefits you.

\section{Repository Citation}

Frye, Brian L. and Ryan, Christopher J., "An Empirical Study of University Patent Activity" (2017). Law Faculty Scholarly Articles. 617.

https://uknowledge.uky.edu/law_facpub/617

This Article is brought to you for free and open access by the Law Faculty Publications at UKnowledge. It has been accepted for inclusion in Law Faculty Scholarly Articles by an authorized administrator of UKnowledge. For more information, please contact UKnowledge@lsv.uky.edu. 


\section{An Empirical Study of University Patent Activity}

\section{Notes/Citation Information}

Christopher J. Ryan, Jr. \& Brian L. Frye, An Empirical Study of University Patent Activity, 7 NYU J. Intell. Prop. \& Ent. L. 51 (2017). 
NEW YORK UNIVERSITY

\title{
JOURNAL OF INTELLECTUAL PROPERTY AND ENTERTAINMENT LAW
}

\author{
VOLUME 7
}

FALL 2017

NUMBER 1

\section{AN EMPIRICAL STUDY OF UNIVERSITY PATENT ACTIVITY}

\author{
CHRISTOPHER J. RYAN, JR. \& BRIAN L. FRYE***
}

Since 1980, a series of legislative acts and judicial decisions have affected the ownership, scope, and duration of patents. These changes have coincided with historic increases in patent activity among academic institutions.

This article presents an empirical study of how changes to patent policy precipitated responses by academic institutions, using spline regression functions to model their patent activity. We find that academic institutions typically reduced patent activity immediately before changes to the patent system, and increased patent activity immediately afterward. This is especially true among research universities. In other words, academic institutions responded to patent incentives in a strategic manner, consistent with firm behavior, by reacting to the preferences of internal coalitions to capture unrealized economic value in intellectual property.

** Christopher J. Ryan, Jr., American Bar Foundation \& AccessLex Institute Doctoral Fellow, American Bar Foundation. Ph.D. Candidate, Vanderbilt University; J.D., University of Kentucky; M.Ed., University of Notre Dame; A.B. Dartmouth College. Brian L. Frye, SpearsGilbert Associate Professor of Law, University of Kentucky School of Law. J.D., New York University School of Law; M.F.A., San Francisco Art Institute; B.A, University of California, Berkeley. This article was presented at the Searle Center Roundtable on Patents and Technology Standards in Chicago, IL on May 4, 2017. The authors would like to thank the organizers of the conference and the attendees whose comments were essential to the article's refinement, including Alan Marco, as well as our colleagues at the American Bar Foundation, Vanderbilt University, and the University of Kentucky whose comments helped us improve the article in its formative stages, especially Steph Didwania, Ben Skinner, Walker Swain, Richard Blissett, and Luis Rodriguez. 
University patent activity, as a response to patent law changes, carries important economic and normative implications. The patent system uses private economic incentives to promote innovation, but academic institutions are charitable organizations intended to promote the public good. This study demonstrates that patent incentives may have encouraged academic institutions to invest in patentable innovation - in ways that potentially limit access to innovation-in order to internalize private economic value.

INTRODUCTION

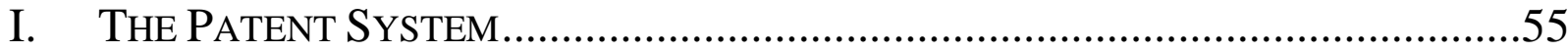

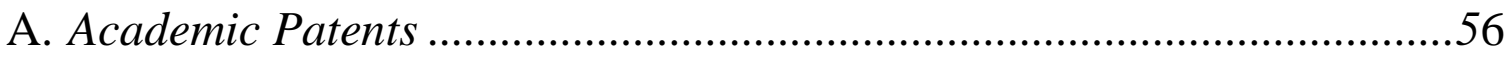

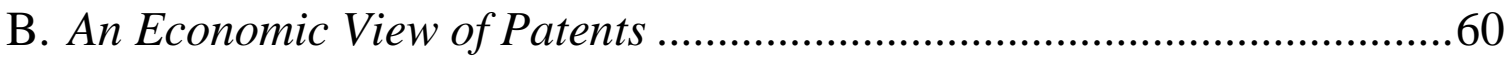

C. University Responses to Patent Policy Incentives....................................61

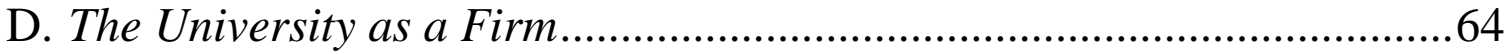

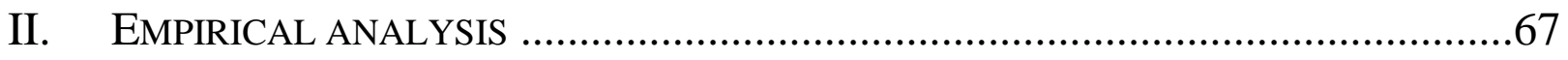

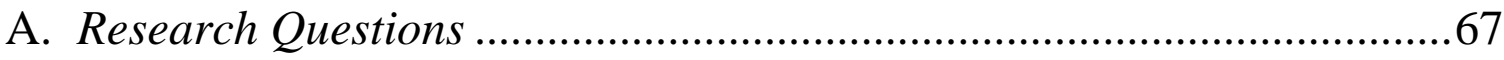

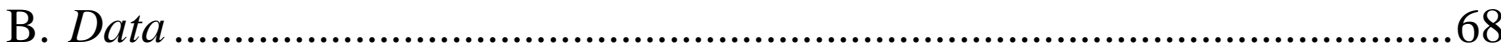

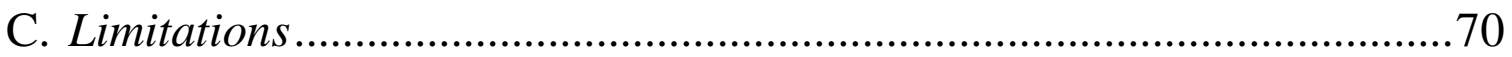



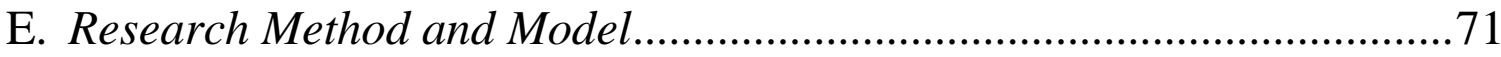

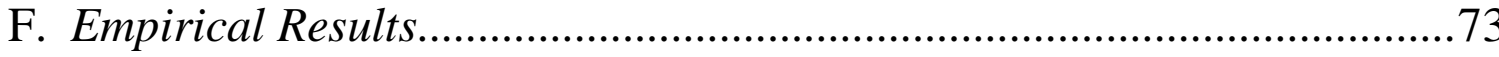

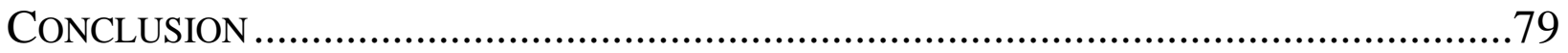




\section{INTRODUCTION}

Since in the last quarter of the 20th Century, the United States patent system has been in a state of flux, influencing not only patent law but the incentives underlying invention and patent ownership. A series of legislative acts and judicial decisions, beginning in 1980, have affected the ownership, scope, and duration of patents. In 1980, the Bayh-Dole Act enabled academic institutions to patent inventions created from federally-sponsored research. ${ }^{1}$ In 1994, Congress extended the maximum duration of a United States patent from 17 to 20 years for certain patents, increasing the monopolistic value of patent protection. ${ }^{2}$ And in 2011, the America Invents Act shifted the patent system from a first-to-invent standard to a first-to-file system. ${ }^{3}$ These changes have impacted all inventors but especially those at academic institutions, where research is a multi-billion dollar industry; perhaps relatedly, these changes have coincided with historic increases in patent activity among academic institutions.

This patent activity is not necessarily unexpected, inefficient, or objectionable. After all, academic institutions are charitable organizations and intended to promote the public good of innovation, among other things. Many academic institutions, especially research universities, rely on significant federal investment to support research that promotes the dissemination of knowledge, disclosure of new knowledge, and importantly, innovation. In theory, the patent system could do even more to encourage academic institutions to invest far greater resources in innovation.

However, university patent activity has important economic and normative implications. The patent system uses private economic incentives to promote innovation. Accordingly, it creates an incentive for universities to overinvest in patentable innovation and limit access to innovation, in order to internalize private economic value. This is especially troubling because universities may use publiclyfunded research to generate patentable innovations for private gain. Thus, concerns about transparency and efficiency arise when considering the extent from which universities may ultimately derive private monetary benefit from public investment, especially given that universities lack the capacity to bring an

${ }^{1}$ Patent and Trademark Law Amendments (Bayh-Dole) Act, Pub. L. No. 96-517, 94 Stat. 3015, 3019 (1980).

${ }^{2}$ See Uruguay Round Agreements Act, Pub. L. No. 103-465, 108 Stat. 4809, 4984 (1994) (codified at 35 U.S.C. $§ 154(a)(2)$ (1994)).

${ }^{3}$ See Leahy-Smith America Invents Act, Pub. L. No. 112-29, 125 Stat. 284, 285 (2011). 
invention to market. ${ }^{4}$ That is, as a non-practicing entity, in order to internalize the economic value of their research, universities must acquire patent protection over their inventions. However, because they do not have the capacity to bring their inventions to market, universities can and do use public funds to produce research yielding patents that are worthless or, worse yet, transfer their patents rights to patent assertion entities rather than practicing entities, producing externalities and inefficiency in the patent system. ${ }^{5}$

While the purposes of the patent system are manifold, these sorts of behaviors undercut the argument that patents contribute to innovation. Thus, there is a founded concern that academic institutions have responded to patent incentives in ways that may actually limit access to innovation. Yet, this concern is not the only cause for unease about inefficient responses to patent incentives. ${ }^{6}$ For example, most of the patent infringement actions heard in a handful of district courts that have been described as engaging in forum selling - being a friendly forum for cases filed by patent assertion entities that choose the forum based on its

\footnotetext{
${ }^{4}$ See generally StUART W. LESLIE, THE COLD W AR AND AMERICAN SCIENCE: THE MiLITARYIndustrial ACADEMIC COMPLEX AT MIT AND STANFORD (1993); Christopher P. LOSS, Between Citizens and the State: The Politics of American Higher Education in the 20TH CENTURY 224-25 (2012).

5 See generally DAVID MOWERY, ET AL., IVORY TOWER AND INDUSTRIAL INNOVATION: UNIVERSITY-INDUSTRY TECHNOLOGY TRANSFER BEFORE AND AFTER THE BAYH-DOLE ACT (2015) (noting the trend of universities to transfer patent rights to patent assertion entities in recent years); Donald S. Siegel, David Waldman \& Albert Link, Assessing the Impact of Organizational Practices on the Relative Productivity of University Technology Transfer Offices: An Exploratory Study, 32 Research Pol'y 27 (2003) (analyzing productivity in university technology transfer offices and finding that many are only successful at litigating infringement, not bringing the technology to market); GARY W. MATKIn, TECHNOLOGY TRANSFER AND THE UNIVERSITY (1990) (exploring university patent transfer after the Bayh-Dole Act).

${ }^{6}$ For instance, the Supreme Court recently limited the scope of patent venue in its unanimous decision in TC Heartland v. Kraft Foods, which was motivated by flagrant "forum selling" in the district courts. TC Heartland vs. Kraft Foods Group Brands, 137 S. Ct. 1514 (2017). For the Federal Circuit's decision, which was reversed by the Supreme Court, see TC Heartland vs. Kraft Foods Group Brands, 821 F.3d 1338 (Fed. Cir. 2016). Forum selling is an issue many scholars have identified as increasing the costs to innovation. See, e.g., Brian L. Frye \& Christopher J. Ryan Jr., Fixing Forum Selling, 25 U. Miami Bus. L. REV. 1 (2017); Gregory Reilly \& D. Klerman, Forum Selling, 89 S. CAL L. REV. 241 (2016); Chester S. Chuang, Offensive Venue: The Curious Use of Declaratory Judgment to Forum Shop in Patent Litigation, 80 GeO. WASH. L. REV. 1065 (2011); Elizabeth P. Offen-Brown, Forum Shopping and Venue Transfer in Patent Cases: Marshall's Response to TS Tech and Genentech, 25 BERKELEY TECH. L.J. 61 (2010); Yan Leychkis, Of Fire Ants and Claim Construction: An Empirical Study of the Meteoric Rise of the Eastern District of Texas as a Preeminent Forum for Patent Litigation, 9 YALE J.L. \& TECH. 194 (2007).
} 
pro-plaintiff bias. ${ }^{7}$ Many observers are concerned that the concentration of patent assertion activity in certain district courts has increased the cost of innovation. ${ }^{8}$

Similarly, there is legitimate concern that universities contribute to cost and inefficiency by: (1) using public funds to support research that results in often useless patents; or (2) providing the instrumentality for non-practicing entities to increase the cost of innovation. That is, universities may participate in driving up the cost of innovation by aggregating patent protection for inventions that are likely to have little market value or that they cannot bring to market and must transfer, even to other non-practicing entities. This article is the first in a series of papers to investigate the relationship between universities and the patent system. In particular, this article addresses whether universities can be said to aggregate patent protection for their inventions systematically or monopolistically, which may indicate their role in increasing the cost of innovation. The discussion and results, below, suggests that academic institutions have responded to patent policy changes not in a manner consistent with firm behavior, by accruing property rights when incentivized by patent policy changes to do so, but also by strategically holding out in order to reap greater monopolistic benefit under anticipated patent regime changes, which may have exacerbated the problem of increasing the cost of innovation.

\section{I \\ The Patent System}

The purposes of the patent system are several, but the primary purpose is to promote technological innovation, or rather, to "promote the Progress of . . . useful Arts, by securing for limited Times to . . . Inventors the exclusive Right to their respective . . Discoveries." While some scholars have questioned the efficiency

\footnotetext{
7 See, e.g., Mark Lemley, Where to File Your Patent Case 4-27 (Stanford Public Law, Working Paper No. 1597919, 2010), http://law.stanford.edu/wpcontent/uploads/sites/default/files/publication/260028/doc/slspublic/ssrn-id1597919.pdf; Li Zhu, Taking Off: Recent Changes to Venue Transfer of Patent Litigation in the Rocket Docket, 11 Minn. J.L. SCI. \& TECH. 901 (2010); Alisha Kay Taylor, What Does Forum Shopping in the Eastern District of Texas Mean for Patent Reform, 6 J. MARShall ReV. InTELl. Prop. L. 1 (2006).

${ }^{8}$ See, e.g., Sara Jeruss, Robin Feldman \& Joshua Walker, The America Invents Act 500: Effects of Patent Monetization Entities on US Litigation, 11 DuKE L. \& TECH. ReV. 357 (2012); Tracie L. Bryant, The America Invents Act: Slaying Trolls, Limiting Joinder, 25 HARV. J.L. \& TECH. 697 (2011).

${ }^{9}$ U.S. Const. art. I, $§ 8$, cl. 8. See also, A Brief History of Patent Law of the United States, LADAS \& PARRY, http://ladas.com/a-brief-history-of-the-patent-law-of-the-united-states-2/ (May $7,2014)$. In this article, the term "patent" is used to refer exclusively to utility patents. While the
} 
of the patent system, and other scholars have suggested that it may only provide efficient incentives in some industries, conventional wisdom assumes that it is generally efficient, providing a net public benefit by encouraging investment in innovation. ${ }^{10}$ In any case, while the patent system has always provided essentially identical incentives to inventors in all industries, the demographics of patent applicants and owners have changed over time. Originally, many patent applicants and owners were individual inventors, but for quite some time, the overwhelming majority of patent applicants and owners have been both for-profit and non-profit corporations. An increasing number of those corporate patent applicants and owners are academic institutions. ${ }^{11}$

\section{A. Academic Patents}

Academics have always pursued patents on their inventions with varying degrees of success. But academic institutions did not meaningfully enter the patent business until the early 20th century, and even then, they did so only tentatively. ${ }^{12}$ In 1925, the University of Wisconsin at Madison created the first university patent office, the Wisconsin Alumni Research Foundation, an independent charitable organization created in order to commercialize inventions created by University of Wisconsin professors. Similarly, in 1937, MIT formed an agreement with Research Corporation, an independent charitable organization, to manage its patents. ${ }^{13}$ Many

United States Patent and Trademark Office also issues design patents and plant patents, and the United States Code provides for protection of vessel hull designs and mask works, both of which resemble design patents, all of these forms of intellectual property are outside the scope of this article.

${ }^{10}$ See, e.g., JAMES Bessen \& Michael J. Meurer, PATENT FAILURE (2008) (questioning the efficiency of the patent system); William W. Fisher, The Growth of Intellectual Property: A History of the Ownership of Ideas in the United States, in EIGENTUM IM INTERNATIONALEN VERGLEICH 255-91 (1999) (decrying the antitrust implications of intellectual property protection at the exclusion of innovation); Dan L. Burk \& Mark A. Lemley, Is Patent Law TechnologySpecific?, 17 BERKELEY TECH. L.J. 1155 (2002) (observing that the patent system seems to provide efficient incentives in some industries, but not others); but see, e.g., ROBERT P. MERGES, JUSTIFYING INTELLECTUAL PROPERTY (2011) (concluding that the patent system is broadly justified).

${ }^{11}$ See generally JACOB RoOKSBy, THE BRANDING OF THE AMERICAN Mind (2016).

12 See generally LESLIE, supra note 4; LOSS, supra note 4.

13 Research Corporation was formed in 1912 by Professor Frederick Cottrell of the University of California to manage his own inventions, as well as those others submitted by faculty members of other educational institutions. See Frederick Cottrell, The Research Corporation, an Experiment in Public Administration of Patent Rights, 4 J. INDUST. \& ENGINEERING CHEMISTRY 846 (1912). 
other schools followed MIT's lead, and Research Corporation soon managed the patent portfolios of most academic institutions. ${ }^{14}$

Before the Second World War, academic institutions engaged in very limited patent activity, collectively receiving less than 100 patents. But during the war, many academic institutions adopted formal patent policies, typically stating that faculty members must assign any patent rights to the institution. ${ }^{15}$ Gradually, some academic institutions began creating their own patent or "technology transfer" offices. But by 1980, only 25 academic institutions had created a technology transfer office, and the Patent Office issued only about 300 patents to academic institutions each year. ${ }^{16}$

Since then, patent law has increasingly encouraged patent activity at academic institutions. Until 1968, each federal agency that provided research funding to academic institutions had its own patent policy. Some provided that inventions created in connection with federally funded research belonged to the federal government, others placed them in the public domain, and a few negotiated institutional patent agreements with academic institutions, allowing them to own patents in those inventions. In 1968, the Department of Health, Education, and Welfare's introduced an Institutional Patent Agreement, allowing for non-profit institutions to acquire assignment of patentable inventions resulting from federal research support for which the institution sought a patent. However, this policy was not uniformly applied. As such, in 1980, under pressure to respond to the economic malaise of the 1970s, Congress passed the Bayh-Dole Act, which enabled academic institutions to patent inventions created in connection with federally-funded research. ${ }^{17}$ Specifically, the Act provided that, with certain exceptions and limitations, "a small business firm or nonprofit organization" could patent such inventions, if the organization timely notified the government of its intention to patent the invention and gave the government the right to use the

14 See RoOKSBY, supra note 11 , at 130-35.

15 By 1952, 73 universities had adopted a formal patent policy. By 1962, 147 of 359 universities that conducted scientific or technological research had adopted a formal patent policy, but 596 universities reported that they conducted "little or no scientific or technological research" and had no formal patent policy. American Association of University Professors, American University Patent Policies: A Brief History, https://www.aaup.org/sites/default/files/ files/ShortHistory.pdf (last visited Oct. 23, 2017).

16 This increase in patent activity at universities between 1968 and 1980 is almost certainly a response to the Institutional Patent Agreement. See RoOKSBY, supra note 11, at 130-35; American Association of University Professors, supra note 15.

${ }^{17}$ Patent and Trademark Law Amendments (Bayh-Dole) Act, Pub. L. 96-517, 94 Stat. 3015, 3019 (1980). 
invention. $^{18}$ The Act placed certain additional requirements on nonprofit organizations, providing that they could only assign their patents to an organization whose primary function is to manage inventions. Additionally, the nonprofit organizations must share any royalties with the inventor and use the earned royalties only for research or education. The limitation on assignment was intended to encourage academic institutions to assign their patents to charitable organizations, like Research Corporation, but in practice, it led many of them to compete over federal funds only to produce patentable inventions with little value or to assign their patents to patent aggregators or "patent assertion entities." 19

At about the same time, the scope and duration of patent protection began to expand. First, the Supreme Court explicitly expanded the scope of patentable subject matter to include certain genetically modified organisms and computer software. ${ }^{20}$ Then, in 1982, Congress created the United States Court of Appeals for the Federal Circuit, which has exclusive jurisdiction over patent cases and has adopted consistently pro-patent positions. ${ }^{21}$ In 1984, Congress expanded the patentability of pharmaceuticals. ${ }^{22}$ In 1994, Congress ratified the Uruguay Round of negotiations which created the World Trade Organization and extended the maximum duration of a United States patent from 17 years from the date of issue to 20 years from the filing date, marginally increasing the value of a patent. ${ }^{23}$ And in 2011, Congress passed the Leahy-Smith American Invents Act, which amended the Patent Act by, inter alia, moving from a first-to-invent to a first-to-file patent system. ${ }^{24}$

1835 U.S.C. $\$ 202(c)(7)(2011)$.

19 See Mark A. Lemley, Are Universities Patent Trolls?, 18 FordHAM InTELl. Prop. MediA \& EnT. L.J. 611 (2008). But see Jonathan Barnett, Has the Academy Led Patent Law Astray? BERKELEY TECH. L.J. (forthcoming 2017), https://ssrn.com/abstract=2897728.

${ }^{20}$ See Diamond v. Chakrabarty, 447 U.S. 303 (1980) (holding that patentable subject matter included genetically modified organisms); Diamond v. Diehr, 450 U.S. 175 (1981) (holding that patentable subject matter included certain kinds of computer software); Patent and Trademark Law Amendments Act, Pub. L. No. 96-517, 94 Stat. 3015 (1980) (amending 35 U.S.C. § 301 and allowing universities to take title in the patentable results of funded research).

${ }^{21}$ See Federal Courts Improvement Act, Pub. L. No. 97-164, 96 Stat. 25 (1982) (creating an appellate-level court, the U.S. Court of Appeals for the Federal Circuit, with the jurisdiction to hear patent cases).

${ }^{22}$ See Drug Price Competition and Patent Term Restoration Act, Pub. L. No. 98-417, 98 Stat. 1585 (1984) (enabling generic pharmaceutical companies to develop bioequivalents to patented innovator drugs).

${ }^{23}$ See Uruguay Round Agreements Act, Pub. L. No. 103-465, 108 Stat. 4809, 4984 (1994) (codified at 35 U.S.C. $\S 154(a)(2)$ ).

${ }^{24}$ See Leahy-Smith America Invents Act, Pub. L. No. 112-29, 125 Stat. 284, 285 (2011). 
All of these changes in patent protection caused an increase in overall patent activity, across all types of inventors.

\begin{tabular}{lcc}
\hline \multicolumn{3}{c}{ TABLE 1: Patent Activity over Time } \\
\hline Year & Applications & Granted Patents \\
\hline 1980 & 104,329 & $61,819^{25}$ \\
1990 & 164,558 & $90,365^{26}$ \\
2000 & 295,926 & $157,494^{27}$ \\
2010 & 490,226 & $219,614^{28}$ \\
2015 & 589,410 & $298,407^{29}$ \\
\hline
\end{tabular}

That said, academic institutions played a role in the growth of nationwide patent activity directly related to the dramatic increases in patent applications and grants between 1980 and 2010. In response to these policy changes, many universities adopted a research model under which federal grants and other public funds were directed at the development of patentable inventions and discoveries, enabling the universities to obtain patents and claim a private benefit. By 1990, more than 200 academic institutions had created technology-transfer offices, and the Patent Office was issuing more than 1,200 patents to academic institutions each year. ${ }^{30}$ In 1995 , universities received over $\$ 15$ billion in research grants from the federal government, a figure that would more than double $— \$ 35.5$ billion — by $2013 .{ }^{31}$

Ironically, while some of the patents granted to academic institutions proved extremely valuable, the overwhelming majority of them are worthless. Most of the technology-transfer offices created by academic institutions produce little revenue when compared with expenditures, and many actually lose money. ${ }^{32}$ In 2013 , the median value among universities reporting revenues from their technology transfer offices was a mere $\$ 1.57$ million; moreover, less than 1 percent of all patent

25 See United States Patent And TRAdemark OfFice Patent TeChnOlogy Monitoring Team, U.S. Patent Statistics Chart, Calendar Years 1963 - 2015 (2016), https://www.uspto.gov/web/offices/ac/ido/oeip/taf/us_stat.htm.

${ }^{26} I d$.

${ }^{27} I d$.

${ }^{28} I d$.

${ }^{29} \mathrm{Id}$.

30 See RoOKSBY, supra note 11 , at 130-35.

31 Association of University Technology MANAgers (AUTM) STATT Database, www.autm.net/resources-surveys/research-reports-databases/statt-database-\%281\%29/.

${ }^{32}$ See RoOKSBY, supra note 11, at 139-50. See also Joseph Friedman \& Jonathan Silberman, University Technology Transfer: Do Incentives, Management, and Location Matter?, 28 J. TECH. TRANSFER 17 (2003); MOWERY, ET. AL., supra note 5, at 24-40. 
licenses for patents held by universities and their technology transfer companies generate revenues reaching or exceeding $\$ 1$ million. ${ }^{33}$

\section{B. An Economic View of Patents}

The prevailing theory of patents is the economic theory, which holds that patents are justified because they solve market failures in innovation caused by free riding. In the absence of patents, inventions are "pure public goods," because they are perfectly non-rivalrous and nonexcludable. ${ }^{34}$ Neo-classical economics predicts market failures in public goods, because free riding will prevent marginal inventors from recovering the fixed and opportunity costs of invention. ${ }^{35}$ Under the economic theory, patents solve market failures in innovation by granting inventors certain exclusive rights in their inventions for a limited period of time, which provide salient incentives to invest in innovation. ${ }^{36}$

Patents may also cause market failures by granting inefficient rights to inventors and imposing transaction costs on future inventions. ${ }^{37}$ In theory, patent law can increase net economic welfare by granting patent rights that are salient to marginal inventors and encourage future inventions. In practice, however, patent law may grant rights that are not salient to marginal inventors and discourage future inventions. For example, patent law may cause market failures by discouraging marginal inventors from investing in innovation.

The American patent regime has precipitated "arms race" and "marketplace" paradigms, both of which elicit firm behavior. ${ }^{38}$ In the first instance, the benefits of patent protection incentivize innovators to aggregate under the auspices of the firm model, thereby reducing the marginal cost to each innovator of producing patentable technology. The marketplace paradigm encourages innovation, or at

33 See AUTM STATT Database, supra note 31; see also RoOKSBY, supra note 11, at 139.

${ }^{34}$ See Francis M. Bator, The Anatomy of Market Failure, 72 Q. J. ECON. 351, 377 (1958).

35 See, e.g., Kenneth J. Arrow, Economic Welfare and the Allocation of Resources for Invention, in READINGS IN INDUSTRIAL ECONOMICS, 219-36 (1972); Francis M. Bator, The Anatomy of Market Failure, 72 Q. J. ECON. 351 (1958); Charles M. Tiebout, A Pure Theory of Local Expenditures, 64 J. POLITICAL ECON. 416 (1956).

36 See Richard PoSNER, ECONOMIC ANALYSIS OF LAW $§ 3.3$, at 48-50 (8th ed. 2011).

37 Because the benefits of patent protection disincentivize the inventor form further innovating the patented invention, patent law can be said to discourage innovation. This is because - from the time the invention is granted a patent - the inventor's costs are sunk, meaning that the inventor must incur new development costs and secure a new patent in order to innovate under the patent law regime. See id. at 38-39.

38 See generally Colleen V. Chien, From Arms Race to Marketplace: The Complex Patent Ecosystem and Its Implications for the Patent System, 62 HASTINGS L. J. 297 (2010). 
least innovation likely to result in patent protection. Both paradigms, however, are subject to the results of the perverse incentives that the patent regime provides, specifically that of patent stockpiling and the rent-seeking behaviors of nonpracticing and patent assertion entities. ${ }^{39}$

The right to exclude is perhaps the most important stick in the bundle of patent protection rights and may have the effect of stifling rather than promoting innovation. ${ }^{40}$ As the ubiquity of non-practicing and patent assertion entities in the patent market become commonplace, patent holdup, patent litigation, and patent thickets are common features of the modern patent marketplace. ${ }^{41}$

\section{University Responses to Patent Policy Incentives}

From the perspective of the theoretical literature, innovation depends upon innovators receiving the benefits of their innovation; the regime that allocates these benefits to the innovator and thereby incentivizes innovation is the most efficient. ${ }^{42}$ For universities, a majority of which relied on federal funding to support research and development of patentable innovation during the 20th Century, the patent

${ }^{39}$ Id. See also Thomas L. Ewing, Indirect Exploitation of Intellectual Property Rights by Corporations and Investors, 4 HASTINGS SCI. \& TECH. L. J. 1 (2011); but see David L. Schwartz \& Jay P. Kesan, Analyzing the Role of Non-Practicing Entities in the Patent System, 99 CORNELL L. REV. 425 (2014) (arguing that the debate over non-practicing entities should be reframed to focus on the merits of the lawsuits they generate, including patent system changes focusing on reducing transaction costs in patent litigation, instead of focusing solely on whether the patent holder is a non-practicing entity); Holly Forsberg, Diminishing the Attractiveness of Trolling: The Impacts of Recent Judicial Activity on Non-Practicing Entities, 12 PITT. J. TECH. L. \& POL'Y 1 (2011) (centering on the difficulties faced by legislators in attempting to solve the patent troll problem and turns to the recent judicial activity related to patent law allowing for individuallyfocused, closely tailored analysis is examined with an evaluation of four recent court decisions and resulting changes to the patent system).

${ }^{40}$ See Daniel A. Crane, Intellectual Liability, 88 TEX. L. REV. 253 (2009). See also James Boyle, Open Source Innovation, Patent Injunctions and the Public Interest, 11 DuKE L. \& TECH. REV. 30 (2012) (noting that open source innovation is unusually vulnerable to patent injunctions); John R. Allison, Mark A. Lemley \& Joshua Walker, Extreme Value or Trolls on Top? The Characteristics of the Most-Litigated Patents, 158 U. PENN. L. REV. 1 (2009); John R. Allison, Mark A. Lemley \& Joshua Walker, Patent Quality Settlement Among Repeat Patent Litigants, 99 Georgetown L. J. 677 (2011); Colleen V. Chien \& Mark A. Lemley, Patent Holdup, the ITC, and the Public Interest, 98 CORNELL L. REV. 1 (2012).

${ }^{41}$ See Chien \& Lemley, supra note 40 (noting the unintended consequence of the Supreme Court's ruling in eBay v. MercExchange, 547 U.S. 388 (2006), namely, the driving patent forces entities to a different forum, the International Trade Commission (ITC), to secure injunctive relief not available in the federal courts); Thomas F. Cotter, Patent Holdup, Patent Remedies, and Antitrust Responses, 98 J. CORP. L. 1151 (2009).

42 See Ronald Coase, The Problem of Social Cost, 3 J. L. \& Econ. 1 (1960). 
regime did not substantially encourage universities' entry into the patent market until the passage of the Bayh-Dole Act in $1980 .{ }^{43}$ Descriptive research in this area suggests that the Bayh-Dole Act - which allowed universities to patent inventions developed in connection with federally-funded research-increased the number of university participants in the patent market. ${ }^{44}$ Some scholars have also attributed university technology transfer and patent title aggregation as being rooted in the Bayh-Dole Act. ${ }^{45}$

${ }^{43}$ See Brownwyn H. Hall, Exploring the Patent Explosion, 30 J. TECH. TranSFER 35 (2005); U.S. Patent AND TeChNOlOgy OfFice, U.S. College and University Utility Patent GRANTS - CALENDAR YEARS 1969 - 2012, https://www.uspto.gov/web/offices/ac/ ido/oeip/taf/univ/univ_toc.htm (last visited Oct. 23, 2017) (examining the sources of patent growth in the United States since 1985, and confirming that growth has taken place in all technologies); Rosa Grimaldi, Martin Kenney, Donald S. Siegel \& Mike Wright, 30 Years after Bayh-Dole Act: Reassessing Academic Entrepreneurship, 40 RES. POL'Y 1045 (2011) (discussing and appraising the effects of the legislative reform relating to academic entrepreneurship); Elizabeth Popp Berman, Why Did Universities Start Patenting? InstitutionBuilding and the Road to the Bayh-Dole Act, 38 SoC. STUDIES OF SCI. 835 (2008); LESLIE, supra note 4; Loss, supra note 4, at 224-25. But see Elizabeth Popp Berman, Why Did Universities Start Patenting? Institution-Building and the Road to the Bayh-Dole Act, 38 SoC. STUDIES OF SCI. 835 (2008) (noting that while observers have traditionally attributed university patenting to the to the Bayh-Dole Act of 1980, university patenting was increasing throughout the 1970s, and explaining the rise of university patenting as a process of institution-building, beginning in the 1960s).

${ }^{44}$ David C. Mowery, Richard R. Nelson, Bhaven N. Sampat \& Arvids A. Ziedonis, The Growth of Patenting and Licensing by US Universities: An Assessment of the Effects of the BayhDole Act of 1980, 30 RESEARCH POL'y 99 (2001) (examining the effect of the Bayh-Dole Act on patenting and licensing at three universities - Columbia, Stanford, and California-Berkeley - and suggesting that the Bayh-Dole Act was only one of several important factors behind the rise of university patenting and licensing activity); see also Harold W. Bremer, The First Two Decades of the Bayh-Dole Act, Presentation to the National Association of State Universities and Land Grant Colleges (Nov. 11, 2001) (attributing the proliferation of technology transfer to the BayhDole Act).

${ }^{45}$ See, e.g., Jennifer Carter-Johnson, Unveiling the Distinction between the University and Its Academic Researchers: Lessons for Patent Infringement and University Technology Transfer, 12 VANDERBILT J. ENTERTAINMENT \& TECH. L. 473 (2010) (exploring the idea that a faculty member acting in the role of an academic researcher in the scientific disciplines should be viewed in the context of patent law as an autonomous entity within the university rather than as an agent of the university, and arguing that acknowledging a distinction between the university and its academic researchers would revive the application of the experimental use exception as a defense to patent infringement for the scientists who drive the innovation economy and encourage academic researchers to participate in transferring new inventions to the private sector); Martin Kenney \& Donald Patton, Reconsidering the Bayh-Dole Act and the Current University Invention Ownership Model, 38 RES. POL'Y 1407 (2009) (citing the problems with the 
However, these developments point to the fact that universities may be responding to policy interventions - such as the extension of the duration of patents in 1995 and anticipation of the America Invents Act-and, in turn, affecting the patent landscape. ${ }^{46}$ Examples of these responses include shifting investment in research and development toward innovation sectors that are more likely to receive patent protection, particularly those with high renewal rates, and because the US Patent and Trademark Office (PTO) derives more revenue from these sectors, it has the incentive to grant applications from high renewal rate sectors. ${ }^{47}$ Additionally, researchers have noted that the patent regime does not privilege economic development through technological transfer, and may account for both the increase in patent litigation from non-practicing entities, such as universities, as well as rise in rent-seeking behaviors in patent licensing. ${ }^{48}$

Bayh-Dole Act's assignment of intellectual property interests, and suggesting two alternative invention commercialization models: (1) vesting ownership with the inventor, who could choose the commercialization path for the invention, and provide the university an ownership stake in any returns to the invention; and (2) making all inventions immediately publicly available through a public domain strategy or, through a requirement that all inventions be licensed nonexclusively); Liza Vertinsky, Universities as Guardians of Their Inventions, 4 UTAH L. REv. 1949 (2012) (submitting that universities need more "discretion, responsibility, and accountability over the post-discovery development paths for their inventions," in order to allow the public benefit of the invention to reach society, and arguing that, because universities guard their inventions, the law should be designed to encourage their responsible involvement in shaping the post-discovery future of their inventions).

${ }^{46} 35$ U.S.C. $\$ 154$ (1994); 125 Stat. §§ 284-341 (2011).

${ }^{47}$ See Kira R. Fabrizio, Opening the Dam or Building Channels: University Patenting and the Use of Public Science in Industrial Innovation (Jan. 30 2006) (working paper) (on file with the Goizueta School of Business at Emory University) (investigating the relationship between the change in university patenting and changes in firm citation of public science, as well as changes in the pace of knowledge exploitation by firms, measured using changes in the distribution of backward citation lags in industrial patents); Hall, supra note 43 (confirming that growth since 1984 has taken place in all technologies, but not in all industries, being concentrated in the electrical, electronics, computing, and scientific instruments industries); Michael D. Frakes \& Melissa F. Wasserman, Does Agency Funding Affect Decisionmaking?: An Empirical Assessment of the PTO's Granting Patterns, 66 VANDERBILT L. REV. 67 (2013) (finding that the PTO is preferentially granting patents on technologies with high renewal rates and patents filed by large entities, as the PTO stands to earn the most revenue by granting additional patents of these types); Tom Coupé, Science Is Golden: Academic R\&D and University Patents, $28 \mathrm{~J}$. TECH. TRANS. 31 (2003) (finds that more money spent on academic research leads to more university patents, with elasticities that are similar to those found for commercial firms).

48 See Clovia Hamilton, University Technology Transfer and Economic Development: Proposed Cooperative Economic Development Agreements Under the Bayh-Dole Act, $36 \mathrm{~J}$. Marshall L. Rev. 397 (2003) (proposing that Congress amend the Bayh-Dole Act to provide guidance on how universities can enter into Cooperative Economic Development Agreements 
University technology transfer forces academic institutions to make uncomfortable decisions about licensing and litigation. ${ }^{49}$ Many academic institutions have responded to this ethical dilemma by assigning their patents to patent assertion entities in order to obscure their relationship to those patents and avoid the obligation to enforce them. ${ }^{50}$ Despite universities' status as charitable organizations, as patent owners they have a financial incentive to support their research and development enterprises by competing for federal grants, even if it results in patentable inventions for which there is little economic value and limit the use of the knowledge they generate by securing patent rights regardless of whether these inventions have economic value. Either of these scenarios exacerbates the cost of innovation. ${ }^{51}$

\section{The University as a Firm}

In response to the changes in the patent law system between 1980 and 2011, especially the Bayh-Dole Act, academic institutions increasingly adopted a research funding model under which federal research grants and other public funds were focused on the development of patentable inventions. ${ }^{52}$ As previously observed, the total number of patents granted by the Patent Office steadily

patterned after the Stevenson-Wydler Act's Cooperative Research and Development Agreements); Lita Nelsen, The Rise of Intellectual Property Protection in the American University, 279 SCIENCE 1460, 1460-1461 (1998) (describing the inputs and outcomes of university assertion of intellectual property rights); Nicola Baldini, Negative Effects of University Patenting: Myths and Grounded Evidence, 75 SCIENTOMETRICS 289 (2008) (discussing how the university patenting threatens scientific progress due to increasing disclosure restrictions, changes in the nature of the research (declining patents' and publications' quality, skewing research agendas toward commercial priorities, and crowding-out between patents and publications), and diversion of energies from teaching activity and reducing its quality); Lemley, supra note 7 (illustrating that universities are non-practicing entities, sharing some characteristics with trolls but somewhat distinct from trolls, and making the normative argument that the focus should be on the bad acts of all non-practicing entities and the laws that make these acts possible); Jacob H. Rooksby, University Initiation of Patent Infringement Litigation, 10 JOHN Marshall ReV. InTEll. Prop. L. 623 (2011) (revealing similarities between the litigation behavior of universities and for-profit actors, as well as complex and varied relationships between universities, their licensees, and research foundations closely affiliated with universities).

${ }^{49}$ See RoOKSBY, supra note 11, at 150-67. See also MOWERY ET AL., supra note 5, at 24-40.

${ }^{50}$ See RoOKSBY, supra note 11, at 150-67.

51 See generally MOWERY, ET AL., supra note 5; Christopher A. Cotropia, Jay P. Kesan \& David L. Schwartz, Unpacking Patent Assertion Entities (PAEs), 99 MINN. L. REV. 649 (2014); Sara Jeruss, Robin Feldman \& Joshua Walker, The America Invents Act 500: Effects of Patent Monetization Entities on US Litigation, 11 DuKE L. \& TECH. REV. 357 (2013).

${ }^{52}$ See, e.g., Baldini, supra note 48; Berman, supra note 43. 
increased, and so did the percentage of those patents granted to academic institutions. ${ }^{53}$ Soon, participants in the patent law system began expressing concerns about entities that decreased the efficiency of the patent system by merely owning and asserting patents, rather than practicing them. Of course, academic institutions that own patents are non-practicing entities almost by definition, as they exist to create and disseminate knowledge, not produce commercial products. ${ }^{54}$ Even more troubling, many academic institutions assign most or all of their patents to patent assertion entities, the paradigmatic patent trolls. As a result, the way that academic institutions use patents presents a risk of creating "patent thickets that entangle rather than encourage inventors," which is in tension with the charitable purpose of those institutions. ${ }^{55}$

But how did these patent thickets sprout from the soil of the university? The behavioral theory of the firm may help explain why academic institutions responded to incentives created by changes in this way. Unlike neoclassical economics, which uses individual actors as the primary unit of analysis, the behavioral theory of the firm uses the firm itself as the primary unit of analysis. As a consequence, the behavioral theory of the firm provides better predictions of firm behavior with regard to output and resource allocation decisions.

The field of organizational economics emerged in 1937, when Ronald Coase observed that firms emerge when the external transaction costs associated with markets exceed the internal transaction costs of the firm. ${ }^{56}$ Coase's theory of the firm was revolutionized in 1963, when Richard Cyert and James March provided a behavioral theory of the firm, observing that firms consist of competing coalitions with different priorities responding to different incentives. ${ }^{57}$

In the context of funded research, university patent activity can be read as the result of strategic firm decision-making regarding patent output and resource allocation decisions. In fact, the way that patent policy has bent toward rewarding university patent activity through conferral of rights is a direct result of lobbying and decision-making efforts by these universities with lawmakers-evidence of the

${ }^{53}$ See Hall, supra note 43.

${ }_{55}^{54}$ See Lemley, supra note 19.

55 See POSNER, supra note 36, at 50. See also Peter Lee, Patents and the University, 63 DuKE L. J. 1 (2013).

56 See Ronald Coase, The Nature of the Firm, 4 ECONOMICA 386 (1937).

57 See Richard M. Cyert \& James G. March, A Behavioral TheOry of the Firm (Herbert A. Simon ed., Prentice-Hall Inc. 1963). 
bidirectional interaction between universities and external influences. ${ }^{58}$ The behavioral theory of the firm suggests that academic institutions have responded to incentives created by patent law in a manner consistent with firm behavior. ${ }^{59}$ Though heterogeneity of university patent activity does exist, at most intensive research universities, where decisions are made two ways-with executive administrators setting strategic goals for research which are then implemented at lower management levels - intense competition exists between intensive research universities to vie for patent rights and thus profit maximization.

Increasingly, these universities have centralized and ceded title in patents to their foundations and technology transfer offices. ${ }^{60}$ As non-practicing entities, universities bear the transaction costs of developing patented inventions, but they transfer the transaction costs of bringing the invention to market to intermediaries - and get paid for doing so. ${ }^{61}$ As a consequence, the goal of a university is to satisfice rather than maximize results; firms typically focus on producing good enough outcomes, rather than the best possible outcomes, as a function of compromise among internal coalitions with different priorities.

Thus, one could view increased activity immediately after the implementation of a policy conferring greater patent rights not as a random but as a very rational, profit-maximizing response. However, this activity presents issues when the firm actor is a university. Because academic institutions are necessarily non-practicing entities with strong incentives to assign their patents to patent assertion entities in order to extract their economic value-yet the research from which a patentable invention derives is funded largely by public, federal investment - the gray area which universities occupy through their patent activity makes clear that, while they might not be "patent trolls" as Mark Lemley argues, they certainly feed the patent trolls. ${ }^{62}$

58 See LiSA R. LATtuCA \& JoAn S. Stark, Shaping the College Curriculum: ACAdemiC PLANS IN CONTEXT 24 (2d ed. 2009) (modeling visually the interaction between universities and external influences such as governments).

${ }^{59}$ See Berman, supra note 43.

${ }^{60}$ See Bremer, supra note 44.

${ }^{61}$ JENNIFER A. HENDERSON \& JOHn J. SMITH, ACADEMIA, INDUSTRY, AND THE BAYH-DOLE ACT: AN IMPLIED DUTY TO COMMERCIALIZE (2002), http://citeseerx.ist.psu.edu/viewdoc/download? doi=10.1.1.453.1958\&rep=rep1\&type=pdf (noting that such a duty transforms the academiaindustry relationship from the traditional view of disparate entities into a Congressionallymandated partnership, intended to advance technology and benefit the public).

${ }^{6}$ See Lemley, supra note 19. 
This article aims to provide evidence of that very point. As scholars, like Jacob Rooksby, have observed: "[t]he accumulation, use, and enforcement of intellectual property by colleges and universities reflects choices to engage in a system that . . . takes knowledge and information that is otherwise subject to . . . public use and restricts it, by attaching private claims to it." ${ }^{63}$ The result of these restrictions produced by universities' firm behavior through their patent activity and transfer carries real consequences for innovation. While the effects of these consequences are uncertain, the inputs are fairly clear: the prospect of wealthmaximizing motivates activity in university technology transfer. ${ }^{64}$ Yet, the relationship between universities' wealth-maximizing foray into patent acquisition and its connection with patent policy changes, as well as the explanatory theoretical framework of the behavioral theory of the firm for this very sort of activity, have not been established heretofore. In the sections that follow, this article makes this connection with supporting empirical analysis.

\section{II \\ EMPIRICAL ANALYSIS}

\section{A. Research Questions}

While academic institutions have responded to patent incentives in a manner consistent with firm behavior, the optimal firm response does not necessarily produce the optimal social outcome. Organizational economics predicts that firms will respond to external incentives by satisficing results consistent with the consensus of internal coalitions. As a consequence, firms may or may not respond to patent incentives in a manner consistent with the patent system's goal of maximizing innovation. It follows that if academic institutions exhibit firm behavior in relation to patent incentives, they may satisfice internal coalitions at the expense of social welfare. In the context of university patent activity, this behavior could take the form of the pursuit of patent acquisition not because it is a wealth-maximizing or an economically efficient activity but simply because the regulatory conditions are preferable to pursue patent acquisition.

This study asks whether and how changes in patent law have affected the patent activities of academic institutions. Specifically, it asks two questions:

${ }^{63}$ RoOKSBY, supra note 11 , at 16.

${ }^{64}$ See Valerie L. McDevitt et al., More than Money: The Exponential Impact of Academic Technology Transfer, 16 TECHNOLOGY \& INNOVATION 75 (2014). 
(1) To what extent do universities change their patent acquisition strategy in response to changes in patent law?

(2) To what extent do different kinds of universities respond differently to changes in patent law?

To answer these questions, this study analyzes data on the population of academic institutions that were granted one or more patents between 1969 and 2012 in order to determine the impact of policy changes on university patent activity over this time. ${ }^{65}$ Notably, while future papers in this series may engage with such questions, this article does not determine whether academic institutions have responded to changes in patent law in a way that increases or decreases net social welfare. But it can help explain how academic institutions have responded to patent incentives and whether their responses are consistent with firm behavior, laying the foundation for future exploration of whether and how universities may play a role of increasing costs to innovation.

\section{B. Data}

This study relies primarily on a valuable, albeit limited, dataset compiled by the PTO, which records the total number of patents granted per year to each educational institution in the United States between 1969 and 2012. ${ }^{66}$ Because of limitations with this data-for example, the data contain only one measured variable, the total number of patents granted to an institution in a calendar yearthis dataset had to be merged with other datasets to include more explanatory variables for each institution observation over the same length of time. Specifically, this study relied on the available data from the Classifications for Institutions of Higher Education, a Carnegie Foundation Technical Report, which was produced in 1973, 1976, 1987, 1994, 2000, 2005, and 2010. ${ }^{67}$ Because the first three published Carnegie Classification reports-1973, 1976, and 1987-have not been digitized, the use of this data required the authors to hand-code the classification for each observation utilized in the analytical sample.

65 See U.S. PATENT AND TECHNOLOGY OFFICE, supra note 43.

${ }^{66} \mathrm{Id}$.

67 This study employs data from the Carnegie Classification of Institutions of Higher Education, U.S. COLLEGE AND UNIVERSITY UTILITY PATENT GRANTS - CALENDAR YEARS 1973, 1987, 1994, 2000, 2005, 2010, with years 1994, 2000, 2005, and 2010, http://carnegieclassifications.iu.edu/downloads.php (last accessed Oct. 23, 2017). However, because the Carnegie Commission on Higher Education changed its classification standards in 2010, the "basic" classification standard was used to impute these values for each classification observation from 2010 to 2012. 
From the merged dataset, consisting of the full population of highereducation-affiliated institutions that had been granted a patent between 1969 and 2012, an analytical sample had to be drawn from this population to focus on the main university participants in the patent market: research universities; doctoralgranting universities; medical, health, and engineering specialized institutions; and to a lesser extent, comprehensive universities; liberal arts colleges; and other specialized institutions, including schools of art, music, and design, as well as graduate centers, maritime academies, and military institutes. ${ }^{68}$ Due to the paucity of observations in the following subgroups, 31 observations from two-year colleges, corporate entities, and spin-off research institutes were dropped from analysis, preserving 591 university observations. Additionally, given that the University of California system does not differentiate patent activity by institution, choosing instead to have reported patent activity in the aggregate in the PTO dataset, it was removed from the analytical sample.

Because the Carnegie Classifications attribute most administrative units to the parent institution, this study took the same approach, collapsing administrative units, foundations, other organizational entities, and former institutions on the current parent institution. However, each observation that received a separate classification from its parent institution in the Carnegie Classifications was preserved as a separate observation from the parent institution. ${ }^{69}$ The process of

68 The "basic" Carnegie Classifications split Doctoral-Granting institutions into four subgroups: Research Universities I and II, and Doctoral-Granting Universities I and II. Research universities originally were considered the leading universities in terms of federal financial support of academic research, provided they awarded a minimum threshold of Ph.D.'s and/or M.D.'s. Doctoral-granting universities were originally conceived of as smaller operations, in terms of federal funding and doctoral production, but comparable in scope to the research universities. Next, the Comprehensive Universities I and II met minimum enrollment thresholds, offered diverse baccalaureate programs and master's programs, but lacked substantial doctoral study and federal support for academic research. The Liberal Arts Colleges I and II were selected somewhat subjectively in the first several iterations of the Carnegie Classifications; this is particularly the case for Liberal Arts Colleges II, which did not meet criteria for inclusion in the first liberal arts college category but were not selected for Comprehensive University II, either. The Liberal Arts Colleges I included colleges with the most selective baccalaureate focused liberal arts programs. As for the specialized institutions, which are divided into nine categories, the medical, health and engineering schools tended to be stand-alone institutions or institutions affiliated with a parent higher education institution but maintaining a separate campus. Last, the "other specialized institutions" included in the analytical sample are drawn from schools of art, music, and design, as well as graduate centers, maritime academies, and military institutes. Id.

${ }^{69}$ As an illustrative example of collapsing an administrative unit on the parent institution, Washington University School of Medicine was collapsed on Washington University. This also applied to foundations and boards of regents, which were collapsed on the flagship institution, 
collapsing on parent institution reduced the total number of institutions observed from 590 to 366 school observations, each with 44 year observations.

\section{Limitations}

It should be noted that the data are limited by two important factors: (1) a lack of explanatory covariates; and (2) a small sample of higher education institutions relative to the overall population of higher education institutions. In the first instance, because the year observations for each institution comprise a 44-year span, it is impractical to match each institution-year observation with rich, explanatory covariates over that time. Not even the Integrated Postsecondary Education Data System (IPEDS) collected comprehensive data on universities before 1993. As such, the Carnegie Classifications serve as a proxy for more detailed information about each institution during a span of years for which data is virtually impossible to find. Given that the Carnegie Classifications categorizes schools on the basis of its federal funding for academic research, production of doctorates, institutional selectivity, enrollment, and degree programs, the Carnegie Classification for each school makes an ideal proxy for a more complete set of explanatory covariates.

As for the size of the analytical sample relative to the population of institutions of higher education receiving a Carnegie Classification since 1973, this population consisted of 1,387 universities - not counting theological seminaries, bible colleges and two-year colleges - while the analytical sample used in this study comprises 366 universities - 26.39 percent of the population. However, because this study analyzes university patent activity relative to patent policy change, the analytical sample size is necessarily limited to only those universities that have been granted a patent. As such, the analytical sample used in this study can be viewed as representing a nearly complete picture of the population of academic institutions that have successfully engaged in patent activity between 1969 and 2012.

given that the vast majority of observations in this dataset are standalone or flagship institutions; for example, the University of Colorado Board of Regents and the University of Colorado Foundation are collapsed on the University of Colorado, given that no other institution from the University of Colorado system appears in the PTO dataset. Finally, independent institutions within the same university system were treated as different observations: the University of Texas Southwestern Medical Center is distinctly observed from the University of Texas at Austin or even the University of Texas at Dallas, the city in which the University of Texas Southwestern Medical Center is located. 


\section{Descriptive Results}

Research universities and doctoral-granting universities dominate patenting activity and receive an overwhelming majority of patents granted to academic institutions.

\begin{tabular}{lccc}
\hline \multicolumn{4}{c}{ TABLE 2: Analytical Sample by Carnegie Classification } \\
\hline Carnegie Classification & Freq. & Percent & Avg. Patent Total \\
\hline Research I \& II Universities & 100 & 27.70 & 870.42 \\
Doctoral-Granting I \& II Universities & 77 & 21.32 & 193.23 \\
Comprehensive I \& II Universities & 118 & 32.68 & 26.10 \\
Liberal Arts I \& II Colleges & 34 & 9.41 & 27.29 \\
Specialized Institutions: Medical, Health, and Engineering & 35 & 9.69 & 57.80 \\
Other Specialized Institutions & 2 & 0.55 & 2.50 \\
\hline Observations & 361 & 100.00 & 178.52 \\
\hline
\end{tabular}

However, just under half of the analytical sample is comprised of research universities and doctoral-granting universities, which the Carnegie Classifications consider separate but component parts of its doctoral-granting institution category. The average patent totals for research universities dominate all other classification of institution and are over four times as large as the average patent total for doctoral-granting universities. While comprehensive universities account for the largest proportionate classification in the sample, the average patent total for comprehensive universities is among the smallest in the analytical sample. In fact, it is followed only by the smallest classification in proportion and average patent total-other specialized institutions. Medical, health, and engineering schools, while small in number, maintain considerable average patent totals, nearly doubling the patent totals of liberal arts colleges which account for about the same proportion of institutions analyzed in the analytical sample. Across all categories, universities that entered the patent market before the passage of the Bayh-Dole Act buoy patent totals. As such, given their high level of patent activity, the spline regression model results below will especially highlight early entrants as well as research universities, doctoral-granting universities, and medical, health, and engineering schools.

\section{E. Research Method and Model}

This study employs a spline regression approach to identify how universities reacted to changes in patent policy at key points in time between 1969 and 2012. This method is very similar to using a difference-in-differences approach to compare the activity differences between two series of years separated by a point, 
or knot, in time, where the intercept and slope vary before and after the knot. ${ }^{70}$ Spline regression modeling necessitates that the location of the knots be set $a$ priori in order to produce estimates of the non-linear relationship between the predictor and response variables. Doing this requires defining an indicator variable, using it as a predictor, but also allowing an interaction between this predictor and the response variable. ${ }^{71}$ The analytical model employed in this study is as follows:

$$
E\left(P A T_{i} \mid y r_{t}\right)=\beta_{0}+\beta_{1} C C_{i t}+\beta_{2} E E_{i}+\beta_{3} S_{i}+\beta_{4} y r_{t}+\beta_{5}\left(k_{c} \geq y r_{t}>k_{c-1}\right)+\beta_{6} y r_{t}\left(k_{c} \geq y r_{t}>k_{c-1}\right)+\varepsilon_{i t}
$$

Thus, the expectation of the total number of patents granted to school $i\left(P A T_{i}\right)$ in year $t\left(y r_{t}\right)$ is a function of: (1) a vector of the factors attendant to school $i$ in year $t$ as proxied by its Carnegie Classification $\left(C C_{i t}\right)$; $(2)$ a dummy variable for whether or not the school engaged in patent activity before $1980\left(E E_{i}\right)$; (3) a school fixed effect $\left(S_{i}\right)$; (4) the year indicator variable $\left(y r_{t}\right)$; $(5)$ a dummy variable for the location of the indicator year between the critical spline knots $\left(k_{c}, k_{c-1}\right)$; (6) the interaction of the indicator year and the dummy variable for its location between the critical spline knots; and (7) the random error term $\left(e_{i t}\right)$.

Spline knots were set at $1981\left(k_{1}\right), 1996\left(k_{2}\right)$, and $2010\left(k_{3}\right)$ to account for: (1) the passage of the Bayh-Dole Act in 1980, which incentivized universities to engage in patent activity by giving them title to inventions produced from federally-funded research; (2) the expansion of the patent protection duration from seventeen to twenty years in 1995; and (3) the introduction of the America Invents Act, which would pass into law in 2011 and change the right to the grant of a

70 Stata FAQ: How Can I Run a Piecewise Regression in Stata?, UnIV. OF CALIF. Los ANGELES INST. FOR DigITAL RESEARCH AND EDUC. (2016), https://stats.idre.ucla.edu/stata/faq/ how-can-i-run-a-piecewise-regression-in-stata/. Effectively, calculating the slope and intercept shifts by hand using spline regression rescales the variable "year" by centering it on the location of the spline knot. For example, the first spline knot $\left(k_{l}\right)$ is centered on 1981, with all years before it counting up to zero and all years after-but before the next spline knot - counting up from zero. Including the centered "year" variable in the regression equation also requires adding an indicator variable of the intercept before and after the spline knot. Because the model has an implied constant - the intercepts before and after the spline knot should add up to 1 - the overall test of the model will be appropriately calculated by hand. To finish estimating the slope and intercept differences by hand, this regression approach requires the use of the "hascons" option, because of the implied intercept constant. Alternatively, the "mkspline" package in Stata 13 can be used to conduct this estimation. Both approaches were used and yielded substantially similar results. The estimates from using the "mkspline" command are reported below for ease of interpretation.

James H. Steiger, An Introduction to Splines, STATPowER (2013), http://www.statpower.net/Content/313/Lecture\%20Notes/Splines.pdf. 
patent from a first-to-invent standard to a first-inventor-to-file standard. ${ }^{72}$ The final spline knot was not set at 2012 for two reasons. First, because 2012 was the final year of observation in the data set, the spline regression model would not tolerate a post-2012 slope prediction without post-2012 data. Additionally, setting the knot at 2012 would not account for the possibility that universities may have begun reacting to the policy before the effective date of the policy change, as this particular policy change was in the offing for several years before its eventual passage.

From a theoretical perspective, the decision to specify the analytical model with year-after-the-intervention spline knots is defensible on the grounds that it allows an additional calendar year for universities to react to the policy intervention. However, to test the sensitivity of the model and the decision to set the spline knots one year after the policy intervention, the model was specified in multiple formats to include spline knots on the year of the policy intervention, one year before the policy intervention, and two years before the policy intervention. This sensitivity test was undertaken to ensure that the differences in slopes and intercepts throughout year observations were not evidencing a secular exponential curve. Although the year-of-the-intervention slopes and intercepts bore marginal similarities to the results discussed below, which are modeled on year-after-theintervention spline knots, there were significant differences between the year-afterthe-intervention slopes and intercepts reported below and those for year-prior- and two-years-prior-to-the-intervention. Thus, the year-after-the-intervention spline knot specification used in this study is preferable to other specifications, because it rules out the potential threat of secular trends.

\section{F. Empirical Results}

To analyze the effect of the patent policy changes on university patent activity, the regression model provided in the section above was used to calculate both the intercept before and after the policy intervention as well as the slope before and after the policy intervention. Given that the model employed a fixed effect by institution, the regression results reported below can be interpreted as providing an estimate of the intercepts (I) and effects, or slopes (E) preintervention, as well as the marginal intercept shift and slope change after the intervention for universities in the analytical sample. In the first regression table,

7235 U.S.C. $\S 301$ (2006) (permitting universities to take title in inventions and discoveries produced through federally-funded research); 35 U.S.C. $§ 154(a)(2)$ (2006) (extending the duration of patent protection from seventeen to twenty years); 35 U.S.C. § 100(i) (2006) (changing the right to the grant of patent from first-to-invent to first-inventor-to-file). 
Table 2, the results compare early entrants to non-early entrants, demonstrating stark differences between the two groups.

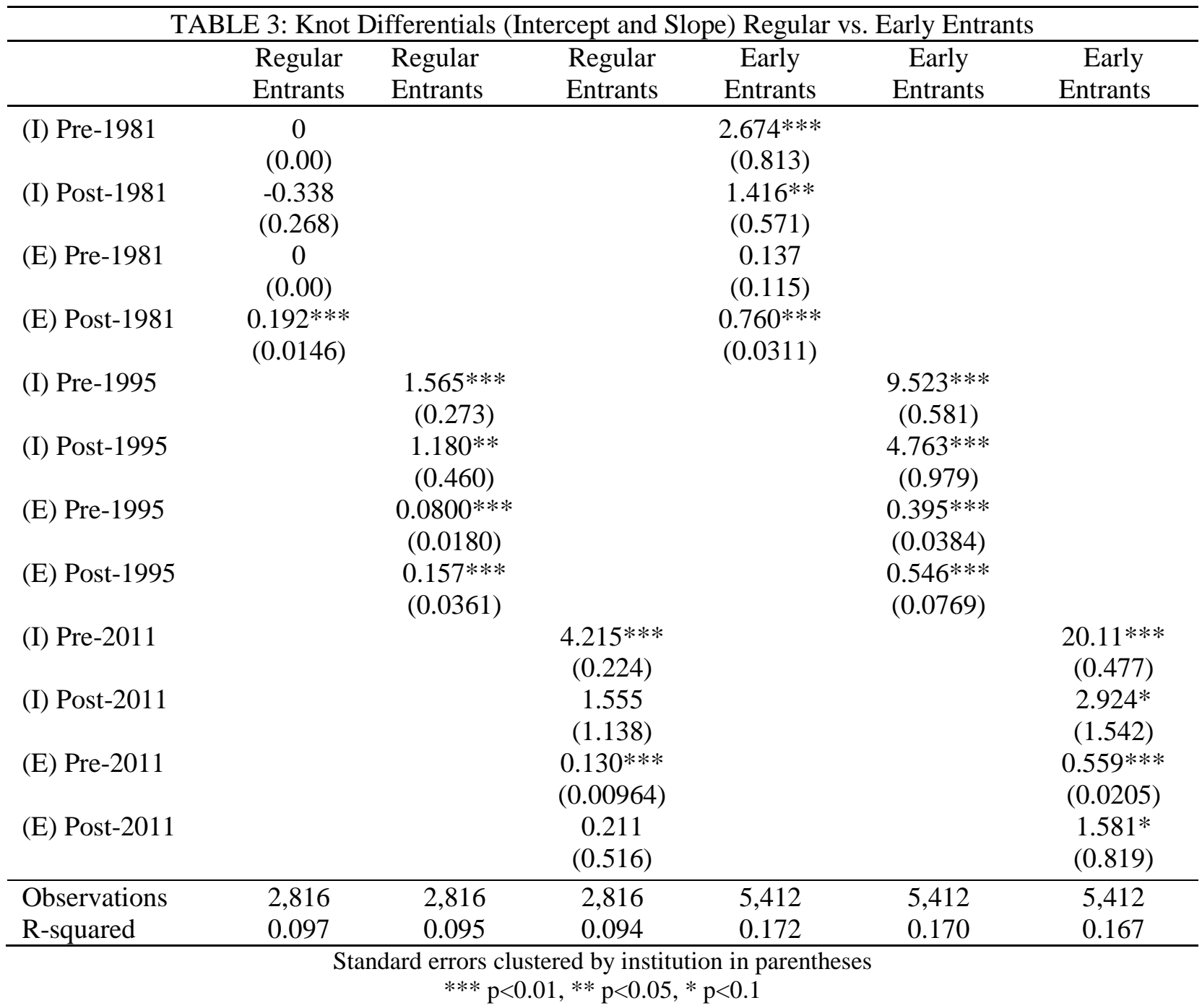

Notably, the early entrants engaged in patent activity at a modest but steady rate, adding minimally to yearly patent totals and averaging 2.67 patents granted annually by 1980 . In 1981, the intercept at this spline knot jumped by an average of nearly one and a half patents in a single year, with an accelerated slope adding to the average growth by three-quarters of a patent every year thereafter to 1994 . By 1995, the intercept spiked again, this time by an additional 4.76 patents granted annually for early entrants, with even further accelerated slope gains to 2010. Finally, in 2011, thought they came close, the estimates lacked statistical significance at the $\mathrm{p}<0.05$ level but indicated an added intercept bump and positive explosion in slope. The non-early entrant estimates, though mostly consistent with 
the statistical significance of the early entrant estimates for the same periods, pale by comparison. The direction and statistical significance of the results for all early entrants are fairly consistent with estimates for the effect of policy changes at the 1981, 1995, and 2011 spline knots among early entrants in the research and doctoral-granting universities classifications.

The results provided in Tables 3 and 4 describe patent activity among early entrant research and doctoral universities, respectively. As Table 3 indicates, research universities achieve the greatest orders of magnitude of increased patent grants at the regression spline knots. Slope changes among this group are statistically significant (or very closely approaching significance in the case of the 1995 spline), illustrating the differential response within group to the various policies while mitigating the influence of secular trends.

\begin{tabular}{|c|c|c|c|c|}
\hline \multicolumn{5}{|c|}{ TABLE 4: Early Entrant Research Universities } \\
\hline Variables & Intercept & Int. Delta & Slope & Slope Delta \\
\hline $\begin{array}{l}\text { 1969-1980 (Beginning of Data) } \\
\text { [11 Years] }\end{array}$ & 105.1 & -- & -0.0523 & -- \\
\hline $\begin{array}{l}1981 \text { Spline \& 1981-1994 } \\
\text { [14 Years] }\end{array}$ & 104.5247 & -0.5753 & $1.1277 * * *$ & +1.180 \\
\hline $\begin{array}{l}1995 \text { Spline \& 1995-2010 } \\
\text { [16 Years] }\end{array}$ & 120.3125 & +15.7878 & $0.8497 *$ & -0.278 \\
\hline $\begin{array}{l}2011 \text { Spline and 2011-2012 } \\
\text { [2 Years] }\end{array}$ & 133.9077 & +13.5952 & $7.5517 * * *$ & +6.702 \\
\hline 2012 (End of Data) & 149.0111 & +15.1034 & -- & -- \\
\hline $\begin{array}{l}\text { Observations } \\
\text { R-squared }\end{array}$ & $\begin{array}{c}\text { Total: } 3,696 \\
0.243\end{array}$ & Years: 44 & Schools: 84 & \\
\hline
\end{tabular}

Doctoral-granting institutions maintained relatively flat-until 2011, when the slope dramatically and significantly changed - but exhibit consistent growth in patent activity around the spline knots. 


\begin{tabular}{lcccc}
\hline \multicolumn{4}{c}{ TABLE 5: Early Entrant Doctoral Universities } & \\
\hline Variables & Intercept & Int. Delta & Slope & Slope Delta \\
\hline 1969-1980 (Beginning of Data) & 0.000 & -- & 0.0178 & -- \\
[11 Years] & & & & \\
1981 Spline \& 1981-1994 & 0.1958 & +0.1958 & $0.1768^{* * *}$ & +0.159 \\
[14 Years] & & & & -0.0284 \\
1995 Spline \& 1995-2010 & 2.671 & +2.4752 & 0.1484 & +1.812 \\
[16 Years] & & & & \\
[2 Years] & 5.0454 & +2.3744 & $1.9604^{* *}$ & -- \\
2012 (End of Data) & 8.9662 & +3.9208 & -- & - \\
\end{tabular}

Observations Total: 2,420

Years: 44

Schools: 55

R-squared 0.129

Standard errors clustered by institution $* * * \mathrm{p}<0.01, * * \mathrm{p}<0.05, * \mathrm{p}<0.1$

Table 5 compares the activity among these two early entrant groups in terms of patents granted. Before the passage of the Bayh-Dole Act in 1980, research universities engaged in steady, relatively flat rates of patent activity, averaging about four patent grants per year. In 1981, the intercept for research universities increased by an average of about two patent grants, significantly adding an average of more than one patent grant per year thereafter. In 1995, the research university intercept jumped over seven units but had a relatively stable slope before and after this time. While the limited data after 2011 do not tolerate statistical significance, research universities and doctoral-granting universities may have undergone another upward intercept shift, but more importantly, may have also undertaken a momentous slope shift, relative to all other slope shifts observed by category, in the years since 2011 . 
TABLE 6: Knot Differentials for Early Entrant Research \& Doctoral-Granting Universities $\begin{array}{lllll}\text { Research } & \text { Research } & \text { Research Doc. Granting Doc. Granting } & \text { Doc. Granting }\end{array}$

Universities Universities Universities Universities $\quad$ Universities Universities

\begin{tabular}{|c|c|c|c|c|c|c|}
\hline \multirow{3}{*}{$\begin{array}{l}\text { (I) Pre-1981 } \\
\text { (I) Post-1981 }\end{array}$} & $\begin{array}{c}3.860 * * * \\
(1.195)\end{array}$ & & & $\begin{array}{c}0.999 * * \\
(0.485)\end{array}$ & & \\
\hline & $1.977 * *$ & & & 0.531 & & \\
\hline & $(0.839)$ & & & $(0.341)$ & & \\
\hline \multirow[t]{2}{*}{ (E) Pre-1981 } & 0.185 & & & 0.0725 & & \\
\hline & $(0.169)$ & & & $(0.0686)$ & & \\
\hline \multirow[t]{2}{*}{ (E) Post-1981 } & $1.117 * * *$ & & & $0.241 * * *$ & & \\
\hline & $(0.0458)$ & & & $(0.0186)$ & & \\
\hline (I) Pre-1995 & & $\begin{array}{c}13.78 * * * \\
(0.855)\end{array}$ & & & $\begin{array}{c}3.450 * * * \\
(0.347)\end{array}$ & \\
\hline \multirow[t]{2}{*}{ (I) Post-1995 } & & $7.302 * * *$ & & & 0.299 & \\
\hline & & (1.439) & & & $(0.585)$ & \\
\hline \multirow[t]{2}{*}{ (E) Pre-1995 } & & $0.569 * * *$ & & & $0.149 * * *$ & \\
\hline & & $(0.0564)$ & & & $(0.0229)$ & \\
\hline \multirow[t]{2}{*}{ (E) Post-1995 } & & $0.787 * * *$ & & & $0.252 * * *$ & \\
\hline & & $(0.113)$ & & & $(0.0459)$ & \\
\hline \multirow[t]{2}{*}{ (I) Pre-2011 } & & & $29.54 * * *$ & & & $6.237 * * *$ \\
\hline & & & $(0.702)$ & & & $(0.283)$ \\
\hline \multirow{2}{*}{ (I) Post-2011 } & & & 3.832 & & & 2.115 \\
\hline & & & (3.568) & & & (1.439) \\
\hline \multirow[t]{2}{*}{ (E) Pre-2011 } & & & $0.822 * * *$ & & & $0.171 * * *$ \\
\hline & & & $(0.0302)$ & & & $(0.0122)$ \\
\hline \multirow[t]{2}{*}{ (E) Post-2011 } & & & 2.291 & & & 0.458 \\
\hline & & & (1.620) & & & $(0.653)$ \\
\hline Observations & 3,256 & 3,256 & 3,256 & 1,584 & 1,584 & 1,584 \\
\hline R-squared & 0.255 & 0.253 & 0.248 & 0.170 & 0.168 & 0.174 \\
\hline
\end{tabular}

Standard errors clustered by institution in parentheses

$* * * \mathrm{p}<0.01, * * \mathrm{p}<0.05, * \mathrm{p}<0.1$

Among early entrant comprehensive universities, only one spline knot approaches statistical significance-the knot at 1995-but even it represents a modest increase from preceding patent activity. 


\begin{tabular}{|c|c|c|c|c|}
\hline \multicolumn{5}{|c|}{ TABLE 6: Early Entrant Comprehensive Universities } \\
\hline Variables & Intercept & Int. Delta & Slope & Slope Delta \\
\hline $\begin{array}{l}1969-1980 \text { (Beginning of Data) } \\
\text { [11 Years] }\end{array}$ & 0.000 & -- & 0.0170 & -- \\
\hline $\begin{array}{l}1981 \text { Spline \& 1981-1994 } \\
\text { [14 Years] }\end{array}$ & 0.187 & +0.187 & 0.0170 & $+4.77 \mathrm{e}-05$ \\
\hline $\begin{array}{l}1995 \text { Spline \& 1995-2010 } \\
\text { [16 Years] }\end{array}$ & 0.4251 & +0.2381 & $0.0484 *$ & +0.0314 \\
\hline $\begin{array}{l}2011 \text { Spline and 2011-2012 } \\
\text { [2 Years] }\end{array}$ & 1.1995 & +0.7745 & 0.0390 & +0.342 \\
\hline 2012 (End of Data) & 1.9804 & +0.7808 & -- & -- \\
\hline $\begin{array}{l}\text { Observations } \\
\text { R-squared }\end{array}$ & $\begin{array}{l}\text { Total: } 1,628 \\
0.072\end{array}$ & Years: 44 & Schools: 37 & \\
\hline
\end{tabular}

Likewise, the statistical significance of the specialty institutions'-including primarily medical, health, and engineering schools - spline knot estimates is only present around the 1981 spline knot. Yet, the results clearly indicate a considerable bump at the 2011 spline knot, despite the lack of statistical significance at that spline or the 1995 spline.

\begin{tabular}{lcccc}
\hline \multicolumn{4}{c}{ TABLE 7: Early Entrant Specialty Institutions } & \\
\hline Variables & Intercept & Int. Delta & Slope & Slope Delta \\
\hline 1969-1980 (Beginning of Data) & 8.594 & -- & -0.00429 & -- \\
[11 Years] & 8.5468 & -0.0472 & $0.1447 * *$ & +0.149 \\
$\begin{array}{l}\text { 1981 Spline \& 1981-1994 } \\
\text { 14 Years] }\end{array}$ & 10.5723 & +2.0259 & 0.0626 & -0.0821 \\
$\begin{array}{l}\text { 1995 Spline \& 1995-2010 } \\
\text { [16 Years] }\end{array}$ & 11.5745 & +1.0018 & 1.3376 & +1.275 \\
$\begin{array}{l}\text { 2011 Spline and 2011-2012 } \\
\text { 2 Years] }\end{array}$ & 14.2497 & +2.6752 & -- & -- \\
2012 (End of Data) & $\begin{array}{l}\text { Total: } 1,056 \\
0.091\end{array}$ & Years: 44 & Schools: 24 & \\
\hline $\begin{array}{l}\text { Observations } \\
\text { R-squared }\end{array}$ & $\begin{array}{c}\text { Standard errors clustered by institution } \\
* * *\end{array}<0.01, * * \mathrm{p}<0.05, * \mathrm{p}<0.1$ & & \\
\hline
\end{tabular}

It is likely that these two groups of institutions - comprehensive universities and specialty institutions - demonstrate relatively little change with the passage of new patent policy for a couple of reasons. First, their numbers are few, especially when compared with research and doctoral-granting universities. Second, and perhaps more important, their missions are very different from research 
universities. ${ }^{73}$ Thus, these universities may not respond to the same incentives in the same way as research and doctoral universities simply because research resulting in a patent may not be an institutional priority for many of the schools in the comprehensive and specialty institution categories.

Notwithstanding these results for the comprehensive universities and specialized institutions, the statistically significant slope and intercept differentials, while controlling for explanatory covariates, indicate the strong presence of university patent activity responses among research and doctoral universities to patent regime changes at the years represented by the spline knots. There is considerable evidence that, among these two categories of universities, the passage of the Bayh-Dole Act in 1980 provided considerable incentive, and elicited considerable effect, on the engagement of major universities in patent acquisition. The shrinking but still significant effect at the 1995 policy intervention, which extended patent duration to 20 years in some but not all patents, may be direct evidence that, because this policy change was not as major a shift in the conferral of rights to universities, it did not elicit the same magnitude of response. However, the anticipation of the passage of the America Invents Act triggered a massive shift in university patent acquisition, perhaps because universities were concerned that their inventions could be scooped under the new first-inventor-to-file standard.

This behavioral pattern suggests a rational, profit-maximizing response - the result of strategic firm decisions regarding patent output and resource allocation decisions - to increase patent activity immediately after the implementation of a policy conferring greater patent rights. However, because universities do not bring these patents to market themselves, and so many of these patents are sold to patent assertion entities, the increase in university patent activity has the effect of contributing substantially to the patent thicket.

\section{CONCLUSION}

This study asks whether universities exhibit patent activity consistent with firm behavior. The results of the spline regression models suggest that research universities and doctorate-granting universities increase their patent activity in direct response to incentives created by changes in patent law but may also strategically hold on to pursue patentable inventions until after the policy provides them more robust patent rights or protection. Most notably, across all university types, the Bayh-Dole Act accelerated patent activity once universities could take title in inventions produced from federally-funded research. As illustrated in the

${ }^{73}$ Kristina M. CRAgG \& PAtrick J. Schloss, Organization AND Administration in HiGHER EDUCATION 3-25 (2017). 
regression models and Figure 1 in the Appendix, this Act may have even incentivized research universities to disengage in patent activity prior to, and scale up patent activity just after, the passage of the act, in anticipation of the benefit that would be conferred upon them once the act had passed into law. As the patent protection duration expanded in the mid-1990s, the growth of patent activity at most universities in the analytical sample increased marginally, indicating another firm response to the patent law regime changes. Finally, preliminary results and the figures in the Appendix indicate that the anticipation of the America Invents Act may have had the largest impact in the rate of patent activity to date, evidence of a university patent activity response to protect current research against a more liberalized granting process.

These responses, evincing a move toward patent aggregation by universities, may have lasting impact not only on the patent marketplace but also on innovation. Yet, patent aggregation, in and of itself, is not necessarily problematic. However, the symptoms of patent aggregation, such as patent hold-up and rent-seeking licensing behaviors, are detrimental to the promotion of innovation. Moreover, competition for federal funds that leads to the production of patentable technology of little economic value could evince another market inefficiency to which universities may substantially contribute.

This study - the first in a series investigating how universities make decisions about their intellectual property, and whether these decisions redound to the public good-demonstrates that research universities, doctoral granting institutions, and specialized institutions respond strategically to patent policy changes in ways that carry profound consequences for innovation and the public good. It is clear that changes to patent policy are necessary to incentivize universities to reap the benefits of research and development of patentable technologies while promoting innovation. 
APPENDIX

Figure 1: Early Entrant Research Universities

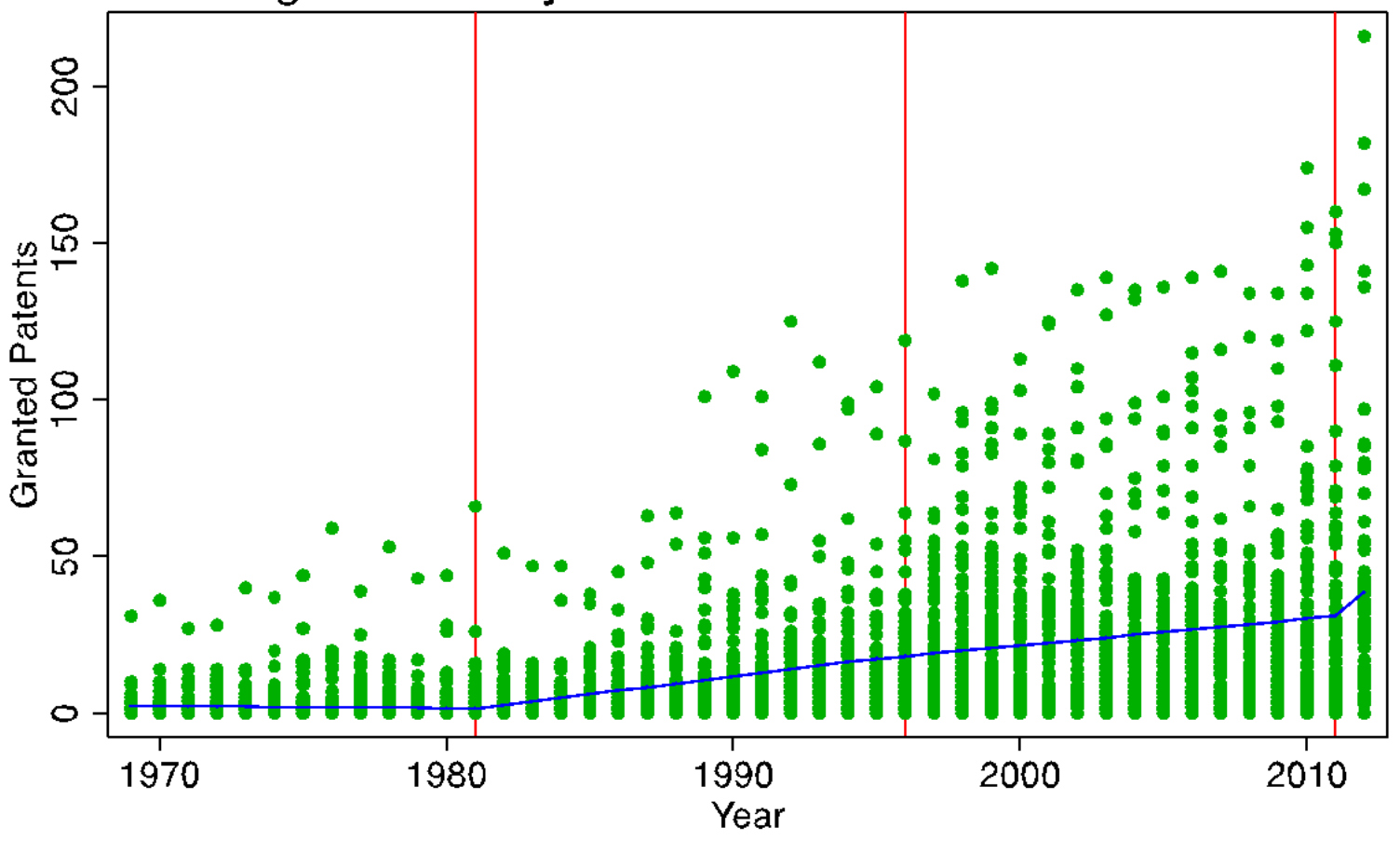


Figure 2: Early Entrant Doctoral Universities

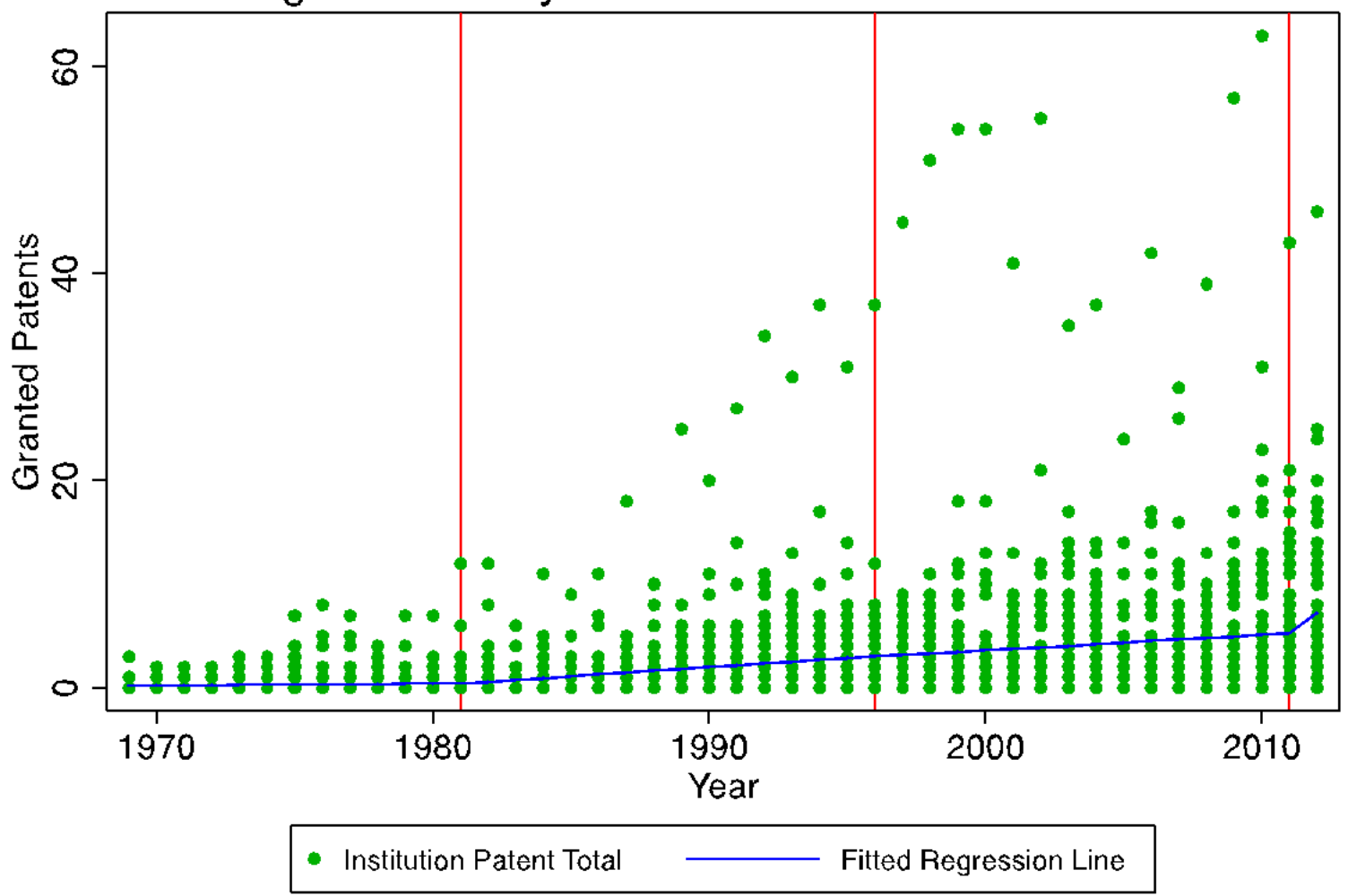


[Vol. 7:1

Figure 3: Early Entrant Comprehensive Universities

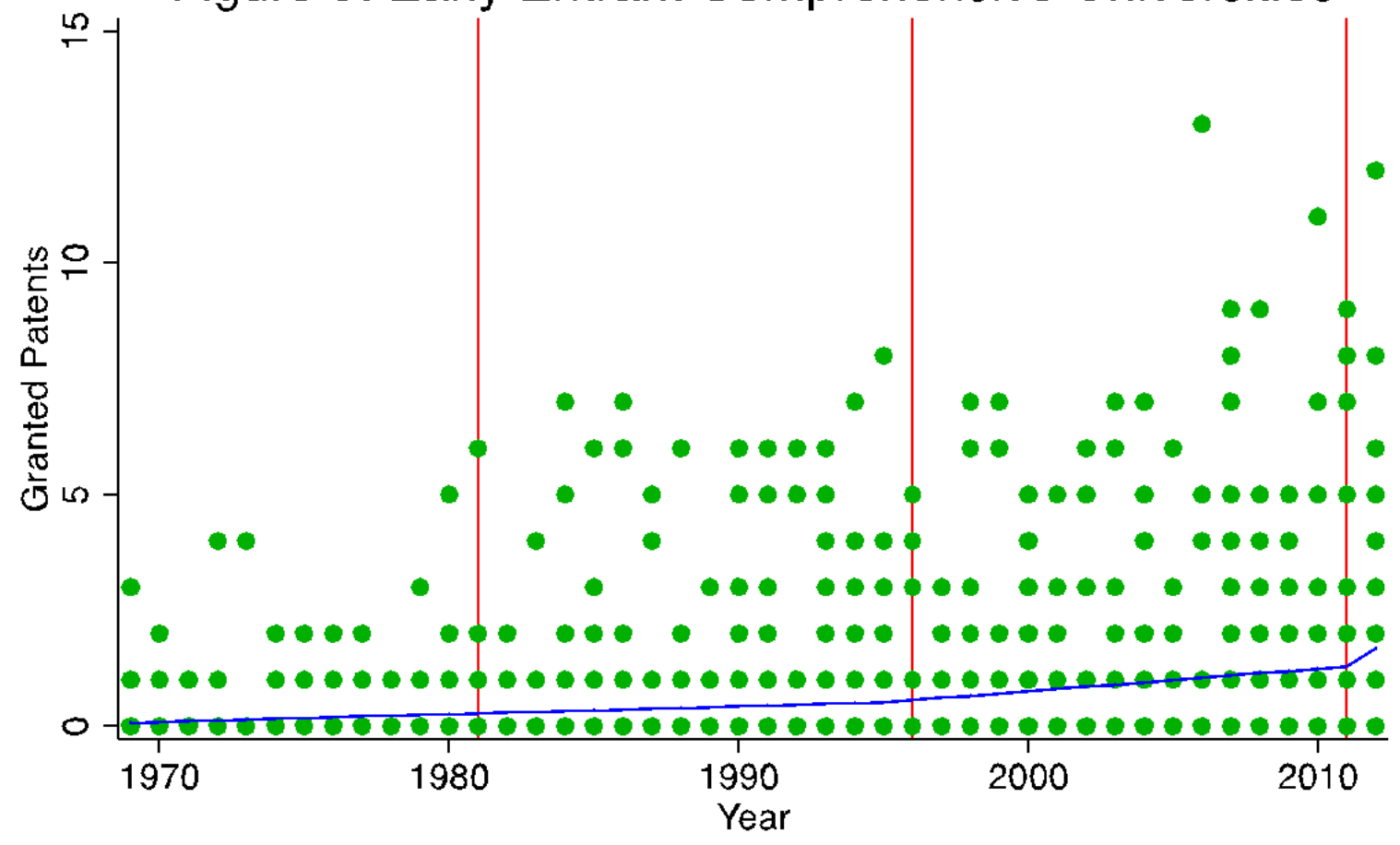

- Institution Patent Total — Fitted Regression Line 


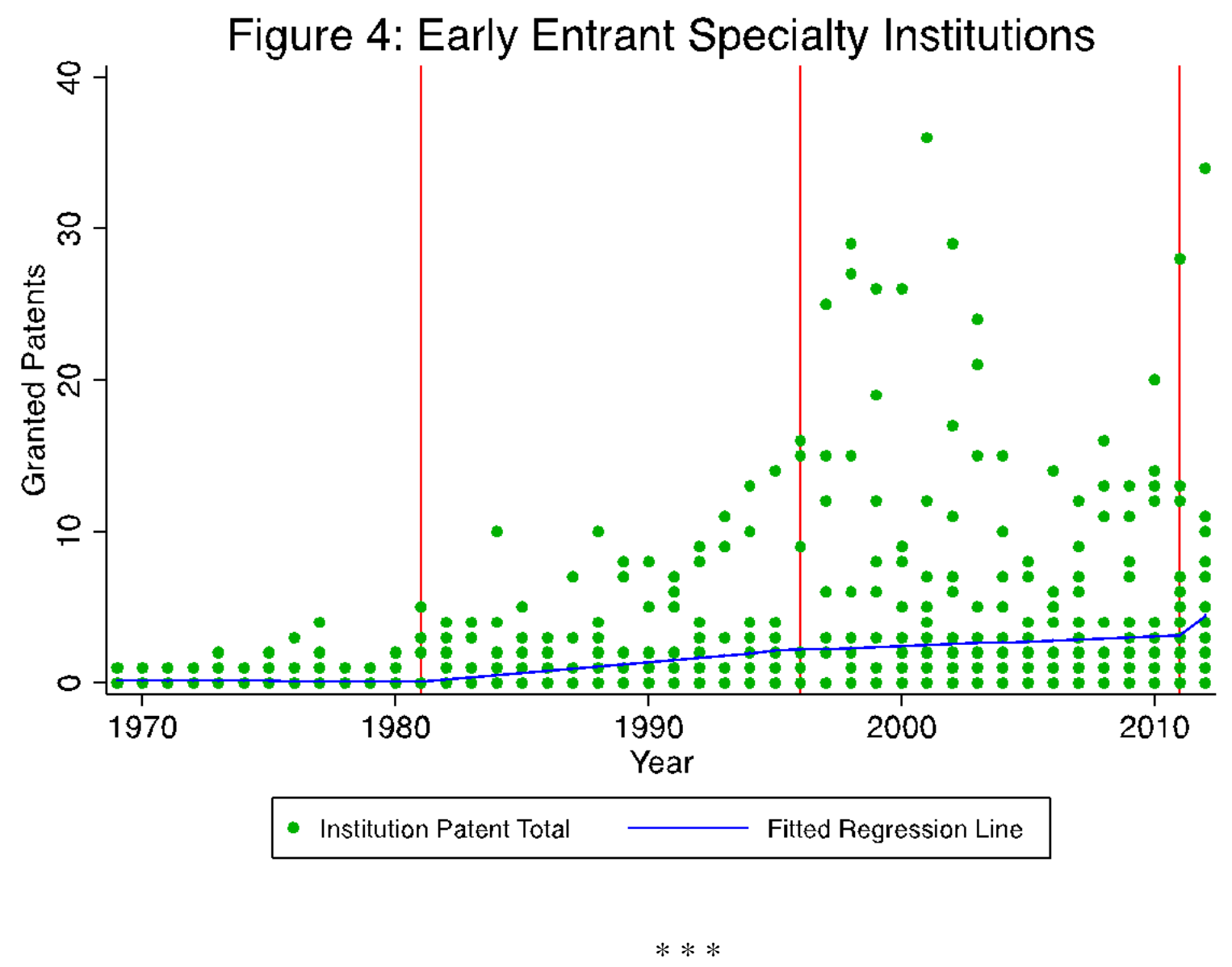

